\title{
Coaching and its effects on individual and organizational performances in Central and Eastern Europe
}

\section{Коучинг и његови ефекти на појединачне и организационе перформансе у Централно-источној Европи}

\section{Szilvia Szabó *}

Metropolitan University of Budapest, Budapest, Hungary

\section{Агнеш Славић **}

Универзитет у Новом Саду, Економски факултет у Суботици, Суботица

Немања Бербер "*.

Универзитет у Новом Саду, Економски факултет у Суботици, Суботица

\begin{abstract}
Coaching as a skill for helping others grow and develop in the workplace has become a major asset in the life of profit-oriented organizations in recent decades. Coaching as a unique practice to develop the human resources of a company can create a partnership between a supervisor and an employee. The aim of the work is to analyze the effects of coaching on productivity and annual staff turnover based on Cranet research from 2015/16 from 9 countries of Central and Eastern European region. The results show that a higher level of the usage of coaching for career management in a company is positively related to the level of productivity and negatively related to the level of staff turnover.
\end{abstract}

Keywords: coaching, individual performances, organizational performances, Cranet, Central and Eastern Europe

Сажетак: Коучинг, као вештина помагања другима с циљем раста и развоја на радном месту, постао је најважнија вредност профитно оријентисаних компанија данашњице. Као јединствена техника за развој људских ресурса компаније, коучинг може да изгради партнерство између супервизора и запослених. Циљ аутора овог рада јесте да анализирају утицај коучинга на продуктивност и годишњу флуктуацију на основу Кранет резултата из 2015/16. године у девет земаља Централне и Источне Европе. Резултати указују на то да је употреба коучинга за развој менаџера у компанијама позитивно повезана с нивоом продуктивности и негативно повезана с нивоом фрлуктуације.

Кључне речи: коучинг, појединачне перформансе, организационе перформансе, Кранет, ЦентралноИсточна Европа

\footnotetext{
*₫ szszabo@metropolitan.hu

** $\bowtie$ slavica@ef.uns.ac.rs

*** $\bowtie$ berber@ef.uns.ac.rs
} 


\section{Introduction}

In the changing word coaching has become an important phenomenon not only for managers and employees but to organizations, too. There are a numerous definitions of coaching. Narrowly, it is a performance imporovement technique. In broader terms it is a context of committed partnership. László et al. (2018) stress that economic goals cannot be achieved without social peace and social cohesion, employers' goals without employees', and vice versa. Therefore coaching plays an important role in organizations.

Coaching is a tool that is capable of creating value that consequently improves the capabilities of human capital. (Hammervoll, 2012) Coaching can be used not only in difficult situations, because it can be applied to numerous problems. It provides tools in individual and organizational levels that help to make important steps on the road to success.

The context of this research is the Central and Eastern Europe (CEE). According to Morely et al. (2016) many of the CEE economies have been on significant development trajectories since the early 1990s, but still, the CEE is underrepresented in the HRM literature. Kazlauskaite et al. (2013) and Morley et al. (2016) emphasized that comparative studies of HRM in the CEE region are important and necessary from both a national and an international perspective because it could serve to establish basic patterns around policy provision in the area and could explain practices and patterns at organisational level and their underlying socio-cultural legitimacy.

The aim of the work is to present data on the usage of coaching for career management among the organizations in CEE region and to analyze its effects on the annual staff turnover and productivity based on Cranet research. The data from 2015/2016 research period is analyzed from 9 countries of Central and Eastern European region: Croatia, Estonia, Hungary, Latvia, Lithuania, Romania, Serbia, Slovakia and Slovenia.

\section{The coaching process}

Coaching may be defined as a broad approach to performance management and as a specific technique of facilitating it (Werner \& DeSimone, 2009). Kinlaw (1999) sees coaching as both problem solving and performance improving and argues that it has made up of four functions: counseling, mentoring, tutoring and confronting.

Coaching is the process of providing one-on-one guidance and instruction to improve knowledge, skills and work performance. As coaching is a skill-focused method, it can be used for knowledge management. While co-workers can be coaches, especially in team-based organizations, more typically it is the supervisor who acts as coach. Supervisors spend on average more than $50 \%$ of their time in such activities. (Blanchard \&Thacker, 1999) 
There are several variants of the concept of coaching, perhaps the most suitable and practically related concept is the following: „The word "coach" means a trainer, a tutor, but the word „trainer" covers this activity the best. Being a coach means to help others achieve those opportunities that they have. The coach makes possible for the clients to unfold themselves from their own power and develop in the desired direction. Coaches can strengthen others to use their competencies in practice and increase their initiative to change." (Szabó \& Szakács, 2015, p. 183)

The coaching process consists of two distinct activities: (1) coaching analysis, which involves analyzing performance and the conditions under which it occurs and (2) coaching discussions, or face-to-face communication between employee and supervisor both to solve problems and to enable the employee to maintain and improve effective performance. (Werner \& DeSimone, 2009)

All in all, the coaching process typically aims the supportive approach to the change and development process of the participant (leader, manager, and client) by focusing on a future goal the client is highly motivated to achieve. The goal is clarified among the actors at the beginning of this special change and development process and it is clear, well-formed and conscientious for both parties. The agreement is sealed by the parties with a written or verbal ,contract” bearing in mind the uniqueness of the unrepeatable and unrepresentative person concerned and in view of this, building upon his or her potential. (Szabó \& Szakács, 2015)

In the coaching process individuals are encouraged to accept responsibilities for their actions, to address any work-related problems, and to achieve and sustain superior levels of performance. Coaching views employees as partners in achieving both personal and organizational goals. (Werner \& DeSimone, 2009)

Coaching is effective as it offers an intense way of learning to employees that is suited to their individual needs and leads to greater career satisfaction. (Utrilla et al., 2015) The currently popular participative management approaches require supervisors, managers and even executives to function largely as coaches for those who report to them. (Werner \& DeSimone, 2009)

\section{The effect of coaching on individual and organizational performances}

In the 21 st century the employees are the most important assets of the companies. Employee development is directly related with employee performance and therefore with the organizations performance, too. Human capital is critical to the success of the organization. Coaching is a tool to improve the development of the human resources and the company itself as it has an influence on individual performance and on organizational performance indicators, too. (Utrilla et al., 2015) 
Coaching is inherently a tool used to develop top leaders and managers, but it can also be effective in enhancing the efficiency of professionals, key people and teams, furthermore it can be used as an organizational and management tool as well. (Szabó \& Szakács, 2015) Usually coaching is directed at employees with performance deficiencies, but it can also be used a motivational tool for those performing adequately. (Blanchard \& Thacker, 1999)

Managing employee performance effectively requires that managers and supervisors become coaches rather than controllers. Acting as a coach makes the manager or a supervisor a partner with employees and a facilitator of their performance. (Werner \& DeSimone, 2009) Fournies (2000) emphasize that effective coaching requires an optimistic, humanistic belief in the desire of employees to be committed to task and organization. On a sample of 576 employees and 112 leaders, Russo et al. (2017) found that coaching leaders are perceived as less manipulative in their performance ratings, especially by older employees.

The studies about managerial coaching behavior found that coaching has an impact on: job performance improvement, self-awareness development, employee satisfaction, satisfaction with work and satisfaction with manager. The research results on the effects of coaching in the insurance sector of Turkey have shown that the managerial coaching behavior has a positive effect on employee satisfaction, organizational commitment, carrier commitment and employee performance, as well. (Kalkavan \& Katrinli, 2014)

Lin et al. (2016) emphasize that higher levels of supervisor coaching provide employees with greater insight regarding how to set career goals, frame career goals in the context of current organizational demands and constraints, as well as how to fulfill these goals. Supervisor coaching facilitates employees' personal growth and career development, raises employee aspirations, provides encouragement and positively affects employee work attitudes and goal-oriented self-regulation, suggesting that coaching plays an important role in aligning the goals of the employee with those of the organization.

The growing number of organizations are using coaching as it is effective in improving performance, correct mistakes and resolve conflicts at the workplace and moreover, in improving the performance of the organization as a whole. The research data show that coaching has a positive effect on employees' productivity level and through it on the organizational performances, too (Bashir \& Shah, 2017; Slavić \& Berber, 2019). Luthan and Peterson (2003) have found that feedback and coaching led to increased employee satisfaction and commitment and reduced turnover intentions. Egan (2017) found that new managers engaged in an executive coaching relationship experienced far greater goal attainment, positive outlooks, and improved performance as compared to their colleagues in a control group. 
Jones et al. (2016) found that coaching has positive effects on organizational outcomes overall and on specific forms of outcome criteria. They examined moderation by a number of coaching practice factors (use of multisource feedback; type of coach; coaching format; longevity of coaching). The analyses of practice moderators indicated a significant moderation of effect size for type of coach (with effects being stronger for internal coaches compared to external coaches) and use of multisource feedback (with the use of multisource feedback resulting in smaller positive effects). Baza et al. (2017) proved that managerial coaching is positively associated with OCB-individual and OCB-Organization with the mediating effects of thriving at work. They emphasize that when managers build good relations, and support their subordinates, valuing the work of their employees, then these behaviors, build a learning and healthy environment, then reciprocally employee feel thrive at work and perform better as compared to those who didn't get coaching and thriving environment.

Based on the analysis of global Cranet research results from 2014/2016, on the data of 6481 respondents from all over the word, Bálint \& Karoliny (2017) state that there is a relationship between the frequency of the usage of career development tools and organ-izational performance. Pousa \& Mathieu (2015) stress that the generalized use of coaching by managers can increase employees' self-efficacy, then the use of managerial coaching by an organization might promote employee self-regulation, increase the organization's general resilience and, thus, can be considered a sustainable competitive advantage. Also, coaching is found to be positively related to the level of innovative performances and service quality in companies in the CEE region (Berber \& Leković, 2018; Slavić \& Berber, 2019).

Human resource management professionals can help managers and supervisors become effective coaches by providing training in the coaching process and ensuring that the coaches have the interpersonal skills needed to be effective. (Werner \& DeSimone, 2009)

\section{Research methodology}

This current research is based on the research data of Cranfield Network of International Human Resources Management (Cranet, 2011). Cranet was established in 1989, and is now a collaboration of more than 40 universities and business schools, representing different countries from all over the world (Mayrhofer et al., 2012).

The questionnaires are filled out by the HRM managers in organizations with more than 50 employees. The questionnaire consists of six sections: HRM activity in the organization, staffing practices, employee development, compensation and benefits, employee relations and communication, organizational details. The questionnaire contained closed-ended questions and respondents were requested to make their choice from sets of alternative, preformulated answers largely covering the specific areas of 
HRM to be studied. The survey concentrates on 'hard data', percentages, ratio etc. and avoids, as far as possible, attitudinal information. To reduce respondent and crosscountry bias very few open-ended questions are included. In addition, the translationretranslation technique is used for every country in every survey round (Morley et al, 2016).

The Cranet Research methodology compared to the beginning (Brewster, 1994) until today has not changed significantly, but rather expanded and enlarged. The research is based on the Cranet international research questionnaire and contains over 60 questions. (Cranet, 2011)

The aim of the work is to present the research data on the usage of coaching for career management among the organizations in CEE region and to analyze its effects on the following organizational performances: annual staff turnover and productivity.

The data analysis is based on Cranet research data from 2014/2016 research period, from 9 countries of Central and Eastern European region: Croatia, Estonia, Hungary, Latvia, Lithuania, Romania, Serbia, Slovakia and Slovenia. The total number of the organizations making the sample is 1064. The sample structure based on the country origin is as follows:

Table 1: Sample structure - country origin (\%)

\begin{tabular}{|l|c|c|}
\hline \multicolumn{1}{|c|}{ Country } & Frequency & $\begin{array}{c}\text { Valid } \\
\text { Percent }\end{array}$ \\
\hline Croatia & 171 & 10,7 \\
\hline Estonia & 83 & 5,2 \\
\hline Hungary & 273 & 17,0 \\
\hline Latvia & 67 & 4,2 \\
\hline Lithuania & 145 & 9,0 \\
\hline Romania & 225 & 14,0 \\
\hline Serbia & 160 & 10,0 \\
\hline Slovakia & 262 & 16,3 \\
\hline Slovenia & 218 & 13,6 \\
\hline Total & $\mathbf{1 6 0 4}$ & $\mathbf{1 0 0 , 0}$ \\
\hline
\end{tabular}

Source: Authors' analysis based on Cranet data

The main share of the sample belongs to SMEs $(45,2 \%)$, to large organizations with 250-1000 employees (38,5\%), while the organizations with more than 1000 employees make only $16,3 \%$ of the sample. Private sector organizations make $70 \%$ of the sample, while the public sector makes $30 \%$. About $30 \%$ of the sample belongs to organizations from the production sector, while services make $70 \%$ of the sample in the CEE countries. The most of the organizations from the production sector belongs to the manufacture of food, beverages, textiles, wood and paper, coke, etc. (10\%).

The authors used the following control variables: size of the organisation - as a number of employees, we used log value; sector of business (private and public); Industry in which the organization operates (production and service sector); trade union 
density (a proportion of employees that are members of trade union), according to Esteban-Lloret et al. (2016) unions influence the employee training and development programs in organizations.

Independent variables were chosen from Cranet database: \% of employees 25 years old and under; \% of employees 50 years old and above; $\%$ of the workforce with a university qualification; existence of written business strategy; existence of a written HRM strategy; existence of a written HR T\&D strategy, primary responsibility for decisions on $\mathrm{T} \& \mathrm{D}$, use of coaching for career management.

Dependent variables were the level of productivity (expressed on a Likert scale, where values go from 1 (poor rate if innovation) to 5 (superior)), and annual staff turnover (expressed by the percentage of employees who left the organization in the given year).

\section{Research results}

In order to test the relationship of each independent variable with the level of productivity and annual staff turnover, the authors used Spearman's correlation and regression analysis. Correlation analysis (table 2) showed that between the independents and the dependent variables there are statistically significant positive weak correlation in the case of the number of employees, the existence of HRM strategy in organization, higher power of HR manager in primary responsibility, the percentage of young employees ( 25 years old and under), the proportion of employees with a higher education qualification, existence of different strategies for HRM, and the usage of caching. Also, correlation analysis showed that between the independents and the dependent variable there are statistically significant negative weak correlation in the case of the sector of the business, trade union density, and the proportion of older employees (50 years and above) employed in the organization.

According to the data in Table 3, the value of 0,306 indicates a moderate level of prediction. $\mathrm{R}$ square value represents the proportion of variance in the dependent variable that can be explained by the independent variables. The coefficient of the determination, $\mathrm{R}$ square, of the final model for the level of productivity is 0,093 which means that the model explains only $9,3 \%$ of the variability of the dependent variable. According to the data in table 4 , the value of 0,404 indicates a moderate level of prediction. The coefficient of the determination, $\mathrm{R}$ square, of the final model for the annual staff turnover is 0,163 which mean that the model explains only $16,3 \%$ of the variability of the dependent variable. The Durbin-Watson statistic is 1,808 (between 1,5 and 2,5) which means that the data is not auto-correlated. The variance inflation factors (VIF) and tolerance also pointed out that there was no multicollinearity in the model. 


\begin{tabular}{|c|c|c|c|c|c|c|c|c|c|c|}
\hline 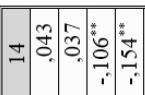 & $\stackrel{:}{\unlhd}$ & $\begin{array}{l}0 \\
\vdots \\
\vdots \\
1 \\
1\end{array}$ & : & ì & 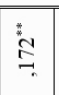 & $\underset{\exists}{z}$ & $\dddot{\Xi}$ & : & \%̊. & \& \\
\hline 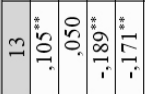 & 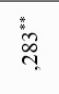 & $\begin{array}{l}1 \\
\vdots \\
\vdots \\
i \\
1\end{array}$ & 足 & $\vec{\Delta}$ & 웅 & o. & ठू. & 落 & $\stackrel{0}{\circ}$ & \%. \\
\hline 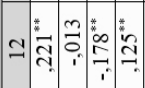 & : & : & î. & $\vdots$ & 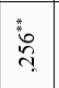 & தे & สิ่ & $\stackrel{-}{-}$ & 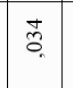 & "ूे \\
\hline 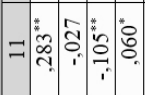 & $\overline{\mathrm{g}}$ & $\begin{array}{l}0 \\
\vdots \\
\vdots \\
\vdots \\
i\end{array}$ & $\tilde{a}$ & str & वे & ڤั & $\underset{-1}{\stackrel{8}{0}}$ & त्र & $\begin{array}{l}\vdots \\
\\
\end{array}$ & $\Xi$ \\
\hline 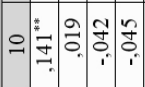 & $\tilde{m}$ & 范 & 。. & ह่ & \begin{tabular}{|l|}
$\vdots$ \\
$\vdots$ \\
$\sigma$ \\
$\sigma$
\end{tabular} & $\underset{-i}{-}$ & है & 亏े & ồ & 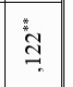 \\
\hline . & : & $\begin{array}{l}\text { in } \\
\text { in } \\
\text { i. }\end{array}$ & $\begin{array}{c}\vdots \\
\vdots \\
\vdots \\
0 \\
0 .\end{array}$ & $\bar{a}$ & $\underset{-}{\circ}$ & "ু & " స్ సे & : & o & $\stackrel{\vdots}{\Xi}$ \\
\hline ठิ & $\overrightarrow{\mathrm{d}}$ & 产 & $\tilde{\tilde{o}}$ & $\stackrel{-1}{-1}$ & $\begin{array}{ll} \\
\\
\end{array}$ & ऊิ & 思 & 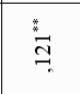 & $\dot{\vec{\sigma}}$ & th. \\
\hline & $\stackrel{\infty}{8}$ & t: & $\underset{-i}{\circ}$ & ๓ె. & $\mid \begin{array}{l}0 \\
\vdots \\
\vdots \\
\vdots\end{array}$ & ه. & $\stackrel{\text { aे }}{0}$ & î. & \begin{tabular}{l|l} 
\\
\\
0 \\
0
\end{tabular} & $\stackrel{0}{0}$ \\
\hline & 点 & $\underset{-}{\circ}$ & is & 落 & $\begin{array}{ll} \\
\vdots \\
b \\
b \\
i \\
\end{array}$ & 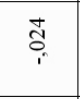 & $\begin{array}{l}0 \\
\vdots \\
\vdots \\
i \\
i\end{array}$ & $\frac{i}{9}$ & \begin{tabular}{|l|} 
\\
$\vdots$ \\
0 \\
7 \\
1
\end{tabular} & \begin{tabular}{|c|}
0 \\
0 \\
0 \\
7 \\
1
\end{tabular} \\
\hline 等 & $\stackrel{8}{\circ}$ & $\frac{1}{i}$ & $\stackrel{\infty}{\circ}$ & $\vec{\Xi}$ & in & $\stackrel{m}{0}$ & $\bar{g}$ & 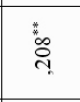 & 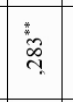 & : \\
\hline & : & : & 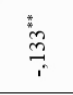 & o & $\overrightarrow{0}$ & so & 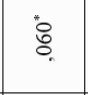 & "ָ & $\stackrel{5}{\square}$ & 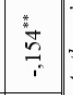 \\
\hline : & 年 & ${ }_{\substack{n \\
m \\
m}}$ & 䒝 & $\stackrel{2}{2}$ & 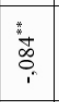 & $\frac{1}{2}$ & 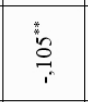 & $\begin{array}{l}\infty \\
\vdots \\
7 \\
7\end{array}$ & 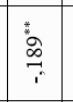 & 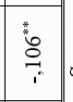 \\
\hline 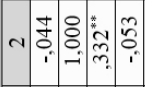 & ఫ্ণ & ô. & $\begin{array}{c}n \\
b \\
\infty \\
m \\
m\end{array}$ & is & $\because$ & छे & î & $\stackrel{m}{i}$ & : & है. \\
\hline & 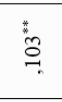 & రి. & $\stackrel{\square}{*}$ & : & $\mid$ & 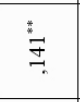 & 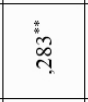 & $\stackrel{*}{*}$ & $\mid \begin{array}{l}\vdots \\
\vdots \\
o\end{array}$ & \%े \\
\hline की & $\vec{g}$ & $\stackrel{+}{+}$ & 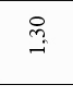 & fo & \begin{tabular}{|l|} 
\\
\\
g.
\end{tabular} & : & ga & $\stackrel{m}{\rightarrow}$ & $\begin{array}{l}\mathbf{I} \\
\\
\end{array}$ & $\underset{\infty}{\infty}$ \\
\hline 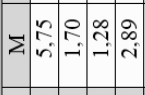 & în & $\underset{m}{\infty}$ & $\underset{\infty}{\infty}$ & t. & $\begin{array}{ll} \\
\\
0\end{array}$ & in & $\overrightarrow{\tilde{i}}$ & $\underset{\sim}{\infty}$ & 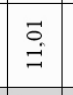 & $\underset{\dot{m}}{\dot{m}}$ \\
\hline 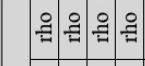 & 맘 & 일 & $z$ & 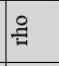 & 욤 & $z$ & $\stackrel{ᄋ}{\sharp}$ & 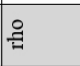 & 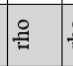 & $\stackrel{\circ}{\sharp}$ \\
\hline$\frac{n}{0}$ & 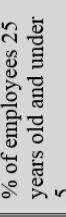 & 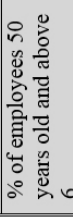 & 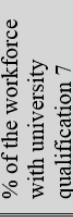 & 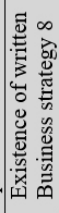 & 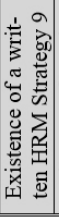 & 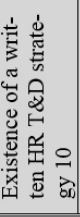 & 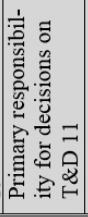 & 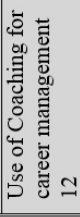 & 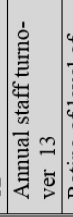 & 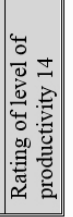 \\
\hline
\end{tabular}


Table 3: Model summary for the level of productivity

\begin{tabular}{|c|c|c|c|c|c|c|c|c|c|}
\hline \multirow[b]{2}{*}{ M } & \multirow[b]{2}{*}{$\mathrm{R}$} & \multirow[b]{2}{*}{$\begin{array}{c}\mathrm{R} \\
\text { Square }\end{array}$} & \multirow[b]{2}{*}{$\begin{array}{c}\text { Adjusted R } \\
\text { Square }\end{array}$} & \multirow[b]{2}{*}{$\begin{array}{c}\text { Std. } \\
\text { Error }\end{array}$} & \multicolumn{5}{|c|}{ Change Statistics } \\
\hline & & & & & $\begin{array}{c}\text { R Square } \\
\text { Change }\end{array}$ & $\begin{array}{c}\mathrm{F} \\
\text { Change }\end{array}$ & df1 & df2 & $\begin{array}{c}\text { Sig. F } \\
\text { Change }\end{array}$ \\
\hline 1 & ,306 & ,093 &, 083 & ,791 &, 008 & 9,187 & 1 & 1049 &, 002 \\
\hline
\end{tabular}

Source: Authors' analysis based on Cranet data

The level of autocorrelation was investigated for the second model. The DurbinWatson statistic is 1.953 (between 1.5 and 2.5) which means that the data is not autocorrelated. The variance inflation factors (VIF) and tolerance pointed out that there was no multicollinearity in the model. The variance inflation factors were lower than the generally accepted threshold of 10 (Hair et al., 1995; Cohen et al., 2003).

Table 4: Model summary for the level of staff turnover

\begin{tabular}{|c|c|c|c|c|c|c|c|c|c|}
\hline \multirow[b]{2}{*}{ M } & \multirow[b]{2}{*}{$\mathrm{R}$} & \multirow[b]{2}{*}{$\begin{array}{c}\mathrm{R} \\
\text { Square }\end{array}$} & \multirow[b]{2}{*}{$\begin{array}{l}\text { Adjusted R } \\
\text { Square }\end{array}$} & \multirow[b]{2}{*}{$\begin{array}{l}\text { Std. } \\
\text { Error }\end{array}$} & \multicolumn{5}{|c|}{ Change Statistics } \\
\hline & & & & & $\begin{array}{l}\text { R Square } \\
\text { Change }\end{array}$ & $\begin{array}{c}\mathrm{F} \\
\text { Change }\end{array}$ & df1 & $\mathrm{df} 2$ & $\begin{array}{c}\text { Sig. F } \\
\text { Change }\end{array}$ \\
\hline 1 &, 404 &, 163 &, 152 & 11,432 &, 010 & 10,274 & 1 & 863 &, 001 \\
\hline
\end{tabular}

Source: Authors' analysis based on Cranet data

Based on the results of the $\mathrm{F}$ test, the model is statistically significant, in case of both dependent variables. The F-ratio in the ANOVA table showed that the overall regression model is a good fit for the data. The independent variables in the final model statistically predict the level of productivity $F(12,1061)=9,000, p<0,001)$ and annual staff turnover $\mathrm{F}(12,875)=14,041, \mathrm{p}<0,001)$.

Table 5 presents the coefficients of the regression model for the level of productivity, as dependent variables. According to the negative beta coefficient $(\beta=-0,062$, $\mathrm{p}<0,05$ ), higher level of trade density is associated with lower level of productivity, when the other variables in the model are controlled. Proportion of employees 25 years old and under is positively related to the level of productivity $(\beta=0,055, \mathrm{p}<0,05)$. Proportion of the workforce with a higher education/ university qualification is also positively related to the level of productivity $(\beta=0,043, \mathrm{p}<0,05)$. The existence of a written HRM strategy in a company is positively related to the level of productivity, too $(\beta=0,170, p<0,01)$. At the end, a higher level of the usage of coaching for career management in a company is positively related to the level of productivity $(\beta=0,058$, $\mathrm{p}<0,01)$.

Table 5: Regression coefficients for the level of productivity

\begin{tabular}{||l|r|r|r||}
\hline \hline & $\mathrm{B}$ & Std. Error & \multicolumn{1}{c|}{$\mathrm{t}$} \\
\hline (Constant) & 3,451 &, 196 & 17,632 \\
\hline Size &, 014 &, 031 &, 458 \\
\hline Size of the company by number of employees &, 007 &, 075 &, 097 \\
\hline Sector &,- 034 &, 072 &,- 474 \\
\hline
\end{tabular}




\begin{tabular}{||l|r|r|r||}
\hline \hline Proportion of employees that are members of a trade union &,- 062 &, 017 & $-3,631^{*}$ \\
\hline Proportion of employees 25 years old and under &, 055 &, 029 & $1,900^{*}$ \\
\hline Proportion of employees 50 years old and above &,- 046 &, 027 & $-1,678$ \\
\hline Proportion of the workforce with a higher education/ university qualification &, 043 &, 021 & $2,029^{*}$ \\
\hline Does your organization have a written Business/service strategy? &, 052 &, 067 &, 770 \\
\hline Does your organization have a written Personnel/HRM Strategy? &, 170 &, 063 & $2,713^{* *}$ \\
\hline Does your organization have a written HR T\&D strategy &, 030 &, 056 &, 528 \\
\hline Who has primary responsibility for major policy decisions on T\&D &, 041 &, 027 & 1,494 \\
\hline Use of Coaching for career management &, 058 &, 019 & $3,031^{* *}$ \\
\hline $\begin{array}{l}\text { Dependent variable: Level of productivity } \\
* * 0,01 \text { level (2-tailed), * } 0 \text {, O5 level (2-tailed) }\end{array}$ & & & \\
\hline
\end{tabular}

Source: Authors' analysis based on Cranet data

Table 6 presents the coefficients of the regression model for the annual staff turnover, as dependent variables. Companies with higher number of employees will have higher level of turnover $(\beta=3,003, p<0,05)$. According to the negative beta coefficient $(\beta=-0,910, p<0,05)$, higher level of trade density is associated with lower level of staff turnover, when the other variables in the model are controlled. Proportion of employees 25 years old and under is positively related to the level of staff turnover $(\beta=3,624, p<0,01)$. Proportion of the workforce with a higher education/ university qualification is negatively related to the level of staff turnover $(\beta=-0,961, p<0,01)$. The existence of a written Business $(\beta=-2,446, p<0,01)$, HRM $(\beta=-2,618, p<0,01)$, and $T \& D$ strategies in a company $(\beta=-2,229, p<0,01)$ is negatively related to the level of staff turnover. At the end, a higher level of the usage of coaching for career management in a company is positively related to the level of productivity $(\beta=0,058$, $\mathrm{p}<0,01)$. Higher involvement of HR managers in T\&D decisions is positively related to the level of staff turnover $(\beta=1,008, p<0,05)$. A higher level of the usage of coaching for career management in a company is negatively related to the level of staff turnover $(\beta=-0,961, p<0,01)$.

Table 6: Regression coefficients for the level of staff turnover

\begin{tabular}{|c|c|c|c|}
\hline & B & Std. Error & $\mathrm{t}$ \\
\hline (Constant) & 5,226 & 3,159 & 1,654 \\
\hline Size & 107 & ,531 & 202 \\
\hline Size of the company by number of employees & 3,003 & 1,214 & $2,474^{*}$ \\
\hline Sector & $-1,175$ & 1,118 & $-1,051$ \\
\hline Proportion of employees that are members of a trade union &,- 910 & ,273 & $-3,334 * *$ \\
\hline Proportion of employees 25 years old and under & 3,624 & ,469 & $7,721 * *$ \\
\hline Proportion of employees 50 years old and above &,- 099 & ,420 &,- 235 \\
\hline Proportion of the workforce with a higher education/ university qualification &,- 961 & ,330 & $-2,911 * *$ \\
\hline Does your organization have a written Business/service strategy? & $-2,446$ & 1,020 & $-2,397 * *$ \\
\hline Does your organization have a written Personnel/HRM Strategy? & $-2,618$ & ,975 & $2,684 * *$ \\
\hline Does your organization have a written HR T\&D strategy? & $-2,229$ & ,889 & $-2,507 * *$ \\
\hline Who has primary responsibility for major policy decisions on T\&D & 1,008 & ,447 & $2,253^{*}$ \\
\hline Use of Coaching for career management &,- 961 & ,300 & $-3,205^{* *}$ \\
\hline
\end{tabular}

Source: Authors' analysis based on Cranet data 


\section{Conclusions}

Coaching is the process of providing one-on-one guidance and instruction to improve knowledge, skills and work performance. It provides tools in individual and organizational levels that help to make important steps on the road to success. Previous researches show that coaching has an impact on: job performance improvement, selfawareness development, employee satisfaction, satisfaction with work and satisfaction with manager.

The Cranet research results from 2015/16 from Croatia, Estonia, Hungary, Latvia, Lithuania, Romania, Serbia, Slovakia and Slovenia confirm that coaching has an impact on individual and on organizational performances, too. The data obtained from 1064 organizations - mainly from private sector - show that a higher level of the usage of coaching for career management in a company is positively related to the level of productivity while a higher level of the usage of coaching for career management in a company is negatively related to the level of staff turnover. This means that the usage of coaching is associated with higher level of productivity and lower level of staff turnover.

\section{References}

Bálint, B., \& Karoliny, Zs. (2017). The More is Applied, the Better Results are Reached? Empirical Lessons Learned from the Usage of Career Management Tools. Strategic Management, 22(4), 3-10.

Bashir, S., \& Shah, F.M. (2017). Relationship Between Employee Coaching and Organizational Performance in Pakistan. RADS Journal of Social Sciences \& Business Management. 4(1), 1-14.

Baza, B., Ali, M., Ahmed, S., \& Moueed, A. (2017). Impact of Managerial Coaching on Employee Performance and Organizational Citizenship Behavior: Intervening Role of Thriving at Work. Pakistan Journal of Commerce and Social Sciences. 11(3), 790813.

Berber, N., \& Lekovic, B. (2018). The impact of HR development on innovative performances in central and eastern European countries. Employee Relations, 40(5), 762-786.

Blanchard, P.N., Thacker, J.W. (1999). Effective Training: Systems, Strategies, and Practices. Upper Saddle River: Prentice Hall.

Brewster, C. (1994). European HRM: reflection of, or challenge to, the American concept? Kirkbridge, P. (ур.). Human Resource Management in Europe. Лондон: Routledge. 
Cohen, J., Cohen, P., West, S. G., \& Aiken, L. S. (2003). Applied multiple regression/correlation analysis for the behavioral sciences (3rd ed.). Њујорк: Lawrence Erlbaum Associates Publishers.

Cranet (2011). Cranet survey on comparative human resource management International executive report 2011. Cranfield: Cranfield School of ManagementCranet.

Egan, T.M. (2017). Executive Coaching and Performance: A Control Theory Perspective. Academy of Management Proceedings. (1)

Esteban-Lloret, N. N., Aragón-Sánchez, A., \& Carrasco-Hernández, A. (2018). Determinants of employee training: impact on organizational legitimacy and organizational performance. The International Journal of Human Resource Management, 29(6), 1208-1229.

Fournies, F.F. (2000). Coaching for improvrd work performance, New York: McGrawHill.

Hair, J. F. Jr., Anderson, R. E., Tatham, R. L. \& Black, W. C. (1995). Multivariate Data Analysis (3rd ed.). Њујорк: Macmillan.

Hammervoll, T. (2012). Managing interaction for learning and value creation in exchange relationships. Journal of Business Research. 65(2), 128-136.

Jones, R.R., Woods, S.A., \& Guillame, Y.R. (2016). The effectiveness of workplace coaching: A meta-analysis of learning and performance outcomes from coaching. Journal of Occupational and Organizational Psychology. 89(2), 249-277.

Kalkavan, S., \& Katrinli, A. (2014). The Effects of Managerial Coaching Behaviors on the Employees' Perception of Job Satisfaction, Organisational Commitment, and Job Performance: Case Study on Insurance Industry in Turkey. Procredia - Social and Behavioral Sciences, 150, 1137-1147.

Kazlauskaite, R., Buciuniene, I., Poór, J., Karoliny, Zs., Alas, R., Kohont, A., \& Szlavicz, A. (2013). Human Resource Management in the Central and Eastern European region. E. Parry, E. Stavrou, \& M. Lazarova, (yp.), Global trends in Human Resource Management (стр. 103-121). Хундмилс: Palgrave Macmillan.

Kinlaw, D.C. (1999): Coaching for commitment: Interpersonal strategies for obtaining superior performance. Сан Дијего: University Associates.

László, Gy., Sipos, N., \& Slavić, A. (2018). The role of trade unions in the HRM of Hungarian and Serbian organizations. Anali Ekonomskog fakulteta u Subotici, 40(54), 67-79.

Lin, W., Wang, L., Bamberger, P.A., Zhang, Q., Wang, H., Guo, W., Shi, J., \& Zhang, T. (2016). Leading future orientations for current effectiveness: The role of 
engagement and supervisor coaching in linking future work self salience to job performance. Journal of Vocational Behavior. 96, 145-156.

Luthan, F., \& Peterson, S.J. (2003). 360 degree feedback with systematic coaching: Empirical analysis suggests a winning combination. Human Resource Management, 42(3), 243-256.

Mayrhofer, W., Sparrow, P., \& Brewster, C. (2012). European human resource management: a contextualized stakeholder perspective. Brewster C. \& Mayrhofer W. (ур.). Handbook of research on comparative human resource management (стр. 528549), Челтенхам: Edward Elgar.

Morley, J. M., Poór, J., Heraty, N., Alas, R., \& Pocztowski, A. (2016). Developments in human resource management in Central and Eastern Europe in comparative perspective. M. Dickmann, C. Brewster, \& P. Sparrow (yp.), International human resource management: Contemporary human resource issues in Europe (стр. 73-99). Лондон: Routledge.

Pousa, C., \& Mathieu, A. (2015). Is managerial coaching a source of competitive advantage? Promoting employee self-regulation through coaching. Coaching: An International Journal of Theory, Research and Practice, 8(1), 20-35.

Russo, S.D., Miraglia, M., \& Borgogni, L. (2017). Reducing Organizational Politics in Performance Appraisal: The Role of Coaching Leaders for Age-Diverse Employees. Human Resource Management, 56(5), 769-783.

Slavić, A., \& Berber, N. (2019). The Role of Training Practice in Improving Organizational Performance in Selected Countries of the Danube Region. Engineering Economics, 30(1), 81-93.

Szabó, Sz., \& Szakács, G. (2015). Közszolgálati HR menedzsment. Будимпешта: Nemzeti Közszolgálati Egyetem.

Utrilla, P.N.C., Grande, F.A., \& Lorenzo, D. (2015). The effects of coaching in employees and organizational performance-The Spanish Case. Intangible Capital, 11(2), 166-189.

Werner, J.M., \& DeSimone, R.L. (2009). Human Resource Development. Mason: South-Western Cengage Learning.

\section{Summary}

Coaching is the process of providing one-on-one guidance and instruction to improve knowledge, skills and work performance. The growing number of organizations is using coaching as it is effective in improving the performance of the organization as a whole. The Cranet research data from 2015/16 from 9 countries from Central and Eastern Europe show that a higher level of the usage of coaching for career 
80 Szilvia Szabó, Агнеш Славић, Немања Бербер

management in a company is positively related to the level of productivity, while a higher level of the usage of coaching for career management in a company is negatively related to the level of staff turnover. 